\title{
Component of Curriculum: Assessment and Testing
}

${ }^{1}$ Like Raskova Octaberlina \& ${ }^{2}$ Andi Asrifan (2021).

${ }^{1}$ Universitas Islam Negeri Maulana Malik Ibrahim, Malang, Indonesia

${ }^{2}$ Universitas Muhammadiyah Sidenreng Rappang

ARTICLE INFO

Keywords

- What is ESP?

- Characteristics of English for Specific Purpose (ESP)

- Assessment in ESP Teaching

- Subcategory of ESP

- Type of ESP

- Instructional materials for ESP teaching

\begin{abstract}
This paper will address what ESP is, our knowledge of English can be strengthened, and ESP in particular. The learning based on teaching the language needed is English for Specific Purposes (ESPs). In Indonesia, in particular for students from outside the English department, the ESP approach is a common option for high school and university students. The implementation of that approach is also consistent with government education policies that stress the goals of learning English, namely improving the ability of students to use English, especially for academic needs and careers, with a special focus on reading skills that enable students to understand authentic material topics effectively by department. The material of teaching influences the content of the course and affects methods of teaching, student motivation and language functions. The ESP aims to ensure that students can master English in the region they study. The assessment of teaching materials helps teachers to develop ESP subjects constantly, and adjust them better to changing student requirements. A student needs survey and their assessment of teaching materials support the theoretical considerations. The results of the survey showed if the needs of students were met in the ESP schools.
\end{abstract}

\section{INTRODUCTION}

EFL has grown into one of the most influential EFL teaching areas of the present day since the beginning of the 1960s. The rise in university graduates at ESP (e.g. Birmingham University and Aston University in the UK) and in ESP courses offered to foreign students from English-speaking countries is a result of this trend. The ESP debates, "English for a Special Purpose: International Journal" and the IATEFL and TESOL GIS ESP groups are currently involved during their National conferences. A very well known International journal is now available. ESP is used to teach students a certain degree of english to understand the use of the language, called goal needs. The ESP teaches English for particular purposes. ESP has grown into one of the most influential fields of international English as it offers educational goals, resources and approaches focused on learners' needs and future interests since the early 1960s. The ESP is currently not only used by adult English learners with a master's degree in English or those who have a specific interest in studying English, but is often used for general English learning by English students.

We must remember that vocational training and learning are increasing fairly rapidly in this age of globalisation. The increasing use of English as a foreign communication language helps someone to understand English better in their work environment. Students begin to learn ESP by mastering EGP (English for General Purposes). There is also a difference in methods and assumptions with regard to English for particular purposes (ESP), such as those of General English (GE). The objectives of ESP are that students can learn English in the area. For instance, chemistry students must understand English for chemistry or if they are engineering students, engineering English or if they are in hospitality, hospitality English should be mastered if they are marine students, maritime English should be mastered. For certain applications in certain fields of science and profession, ESP is typically used in the teaching of foreign languages. This intent is usually considered as an advantage in English for both spoken and written communication. It should therefore be treated as a different General English approach, definition and system. ESP is an English approach with various perspectives, perceptions, styles, materials, judgments and objectives. ESP content applies to students' needs (student requirements) and the individuals who use the graduates. Mc Donough also talked about the meaning and 
concept of ESP. The ESP course must be planned and developed based on the needs of students and graduate users since both students are involved in study or work, as well as in teaching material or as a tuition program. ESP courses are courses which define the study and material in all relevant respects, through prior examination of the communications needs of learners. The ESP is therefore a down-to-earth solution (top button approach).

Based on the above definition, it can be inferred that ESP is a particular approach to English, not a new product. ESP refers to English learning which, depending on their area of expertise and jobs, is geared towards specific needs of students. Materials based on ESP and based on needs analysis are developed.

\section{A. What is ESP?}

ESP is given several meanings. Some people define ESP as simply English teaching for some particular reason. But some are more correct, calling it as English teaching, for vocational or technical purposes, used in academic studies, or as English teaching for non-native English speakers who can study English for particular purposes.

According to Maxwell (2013), the ESP has defined the English language instruction discipline, which focuses on language teaching in specific contexts or which is developed in practice. This may be the learning of limited uses, such as the English required by international waiting staff, in particular registrars in the English language. If the nature of the program, length, and age varies from other disciplines such as TESOL, Tefl, or TESL. Most ESP courses or programmers are aimed at adult students but an ESP is also available entirely for primary and secondary students. And Alice also claimed that ESP is the teaching technique for professionals in different fields, with an emphasis on types of phrases, vocabulary, common and formal frameworks used mostly in a given environment, etc. Business English is the most popular ESP; e.g. English for well, medical English, tourist English, scientific English, etc.

Hutchinson \& Waters (1987, p. 19) describes ESP as a language education strategy that is focused on the learners' encouragement in their decision-making about content and process. Robinson (1991, p.1) regarded ESP as an educational, training and practical enterprise building on three main information realisms, namely language, pedagogy and the field of special interest of students and participants. Richards \& Rodger (2001, p.107) saw ESP as a trend that aims to resolve the language requirements of students who need English to fulfill specific roles (e.g. students, engineers, nurses) and who need to develop content and skills in real life through their mediums rather than mastering language for themselves.

The widespread request from the English language has made ESP more general, but the concept remains the same. Furthermore, the ESP description can be used to differentiate between four absolute and two variables. ESP's four absolute characteristics include teaching the language of the learner: design to suit their particular needs, content-related (i.e. in their themes and subject matter) for a specific discipline, function and action and the language of activity in syntax, lexical, discourse, semanthema, etc.. Although two features are possible for the ESP variable, but not necessarily: restricted to learning the language skills (e.g. reading alone), not previously learned through methodology (Strevens, 1988).

ESP is defined as learning which is focussed on the teaching of the appropriate language from statements made by several experts. Learning English helps our life careers in this sense in that ESP is a form of enhancing English learning in all domains.

\section{B. Characteristics of English for Specific Purpose (ESP)}

ESP has numerous characteristics and features from general English learning as a modern approach to learning English. Of course these features also vary markedly from other language courses like English as a Second Language (ESL) or English as a foreign language (EFL). In learning English, some ESP experts have different and diverse features of ESP. Curriculum creation (SEP) in Christian Gatehouse says four key characteristics of the ESP as an approach to English language learning are namely; (Strevens, 1988)

a) ESP is designed to meet the needs of learners,

b) The substance and content of the ESP is related to themes and topics in a particular field of study, a certain type of work or activity,

c) centered on a language form appropriate to the activity and field of science or work such as syntax, lexical , discourse, semantics, etc., and 
d) ESP is different from General English.

Robinson also said that the ESP has three key features distinguishing between general English or foreign language English (EFL) and mother tongue English (EMT). The three features are;

a) ESP is a learning-oriented target. In this context, students are studying English not because they want to learn the language and culture it includes, but because it has clear, specific and specific goals in one university and professional area, they are learning ESP.

b) ESP substance is established on the basis of the need analysis definition. The idea of needs analysis is to specialize in the academic and technical fields and to get them closer to what learners need;

c) ESP is targeted more at adult students than children or teens. This makes sense because ESP is normally taught at the technical and vocational intermediate or high schools or at work.

Somewhat different from (Strevens, 1988) and Robinson, Evens and Maggie proposed ESP characteristics by using two main terms, namely:

a) absolute characteristics

Absolute characteristics are intrinsic characteristics and are typical of ESP. They further say that the absolute characteristics of ESP are: ESP is designed to meet needs of the learners; ESP makes use of the underlying methodology and activities of the disciplines it serves; ESP is centered on the language (grammar, lexis, and register), skills, discourse, and genre appropriate to these activities.

b) Variability characteristics.

From these quotes, it can be concluded that there are three things related to ESP.

1) The ESP must be design and designed to meet the needs of the learner. With regard to meeting the needs of learners, they added that the essence of ESP to meet the needs of learners means that it focuses on the needs of learners, is effective, is in accordance with the needs of learners, and allows learners to learn successfully in a designed time span. In connection with the needs analysis so that the substance of ESP really fits and meets the needs of learners, (HoadleyMaidment, 1980) in McDonough (1984) suggests that there are three main sources of information in conducting needs analysis, namely, a) instructors, b) learners, and c ) stakeholders.

2) ESP realizes methodologies and activities in accordance with the targeted fields of knowledge or is studied and taught. This means that the methods and activities carried out in classroom learning must be in accordance with the field of science, work, and profession that reflects the variety and diversity of the essence of ESP itself.

3) As a new approach, the focus of ESP is the use of typical language (grammar), skills, discourse, genres appropriate to the activity. In this case, the language coverage in ESP at the level, grammar, semantics, and lexical is different from General English. In addition, another fundamental characteristic of ESP, according to Evens and Maggie, is language skills, discourse and genre.

Consideration of linguistic skills is an important topic in ESP learning which needs to be considered. The emphasis of skills tends to vary from academia and profession to profession in academic or occupational contexts. Academic fields or professions are oriented and focused on speech skills, on the one hand, but academic fields or professions dominate the compose. In addition, ESP has variables that also represent other essences of ESP in contrast to GE or ESL and EFL.

For instance, these variables are:

a) the ESP can employ special situations of learning and various methods of schooling,

b) ESP seems to be more fitting for adult learners in both high and technical workplaces, but ESP can also be used for middle-level learners, b) b)

c) Typically, ESP is intended for intermediate and high-level students, but some ESP instruction also allows beginner-level students.

Two essential points can be taken as inference from the definition above.

a) Absolute characteristics that are fundamental. Absolute and necessary means that certain features are obligatory and have to be included in and are conclusive and irreversible for the advancement of ESP learning.

b) Features which, if optional or more specific, can be classified using the word "should be" or "better or more appropriate." in a word or expression, which still means that those features can be partially or fully updated, created and/or changed in ESP learning. These modifications and changes depend on the ESP context. 


\section{Objectives in ESP Teaching}

The purpose is to identify the behavior pattern that the student wishes to illustrate. The presumption is that ESP teaching is a term which is intended only to help mother English speakers in their target environment cope with linguistic demand, resulting in issues related not only to the objectives for teaching but also the approach to the value of ESP teaching. The aim is to improve ESP teaching.

Stern in Basturkmen (2006) lays out language education priorities into four categories: competence, information objectives, affective targets and transference objectives. The objectives of competence are to learn skills such as reading, writing, listening and speaking. The object of knowledge is to obtain information about language and culture. The linguistic information goals include language analysis and an understanding of language's formal aspects. The aims of cultural awareness include regulating socio-cultural norms, as well as the ability to understand cultural essential facts and to know what is appropriate and not acceptable. Affective objectives are to establish optimistic feelings in the study field. Attitudes towards second language skills, socio-cultural skills and language learning are included. The purpose of the move is to generalize from what is learned in one situation to another. The four target forms are four separate criteria for the ESP instruction, guidelines to make the use of the subject-specific language more apparent.

Competency-based work training can be defined as a method aimed at improving the capacity to conduct the work and perform its functions in accordance with the expected expectations of those working on the job. This goal-driven teaching provides language operationally in language education, in terms of people's language and language skills. Courses are structured around core skills and skills that are often divided into micro skills and advanced skills. This orientation can be identified as a competence objective in accordance with the Stern classification (1992).

Hutchinson and Waters refer to the disciplinary definition of the student area of study for the term underlying competencies at ESP. They argue that ESP should concentrate on improving students' knowledge and linguistic skills in their disciplines. Next, they say that the ESP lessons are a good place for students, who are expected to articulate concepts from disciplines other than languages. They claim, in this case, that ESP teaching must play a part in giving students context details, the so-called essential skills. This means teaching general concept material alongside language, for example, pump systems teaching engineering students while studying language to explain systems and processes. Douglas (2000) provides a three-part model of language skills that include language understanding, morphology, textual, functional and cultures, context knowledge and strategy. He then argues that strategic competence serves as a mediator between the external situation and the internal language and the context information required to respond or that language knowledge and content knowledge are the means by which communication takes place. Each ESP may help to improve students' strategic skills for students with workplaces and professional knowledge or with experience in their discipline.

Dudley-Evans and St. John (1998), in line with the comments made by Hutchinson and Waters, also claimed that students of ESP carry language learning skills and communication from their own specialization fields. In such situations, students may not be able to regulate the language use because it is possible to latent the substance of their field of knowledge (implicit or tacit) so that the function of the instructor is to increase consciousness, in order to get control. ESP teaching can be graded according to the classification of Stern as having the goal of language awareness (1992).

In order to raise critical awareness students should be taught how communicative expectations and practices in the target setting should be developed, encouraged to critique any negative aspects and make students aware of ways of improving or altering the situation so as to better position themselves in relation to it. It can be argued that if teachers increase the consciousness of negative aspects of the students, they can choose to comply. These priorities can be correlated in the Stern classification of cultural awareness and affective targets. This can also be seen as an emotional aim, as teaching aims to improve how students feel and to increase their understanding of their own place, the target environment and the discourse culture. Any ESP course that focuses and concerns should represent the expected learning results at the end of the lesson in the guidance goals formulated from the course. The term "behavioral goals" (Findley \& Nathan, 1980, p 226) is expressed as follows: (1) students as subject; (2) and action verb that describe behavior or success for learning; (3) conditions for demonstrating the learned and (4) minimal performance needed after instruction. This is expressed as follows. 
The dimension of action means that the target defines precisely the actions students take as they accomplish the goal of defining, evaluating and other items. The condition dimension refers to the condition description in which the learner behaves, "Recalling the patient's history with the use of information from the reading text" The minimum level of performance is a list of several actual criteria for carrying out the target, for instance, "must be able to identify at least three differences in microeconomics and macroeconomics at the end of the discussion with the topic of micro and macroeconomics" For educational purposes as Richards \& Rodger suggested (2001, p.123) other characteristics must be fulfilled:

1. they describe the goals needed to achieve in terms of smaller learning units,

2. they provide the basis for the organization of teaching activities, and

3. they describe learning in terms of observable performance behavior.

Richards (2001, p.123-125) contains the declaration of goals which must be clear and accurate in terms of learning outcomes, aligned with curricular goals, and feasible. After determining the learning goals, the subjects to be addressed will be expressed, the tasks to be performed, the amount of instructional materials and the books and materials for the courses to be used.

\section{Assessment in ESP Teaching}

Evaluation is the judge's act. It is a student success assessment in a course. It is the evaluation method of how many educational targets have been accomplished. It offers feedback on the learning of students and therefore on the quality of the educational and learning process. The evaluation aimed two primary objectives, namely to obtain input on supporting learning and comparable ability measures, as reported by Dudley-Evans and St. John (1998).

Evaluation assesses the advantages of learning. Richards and Renandya (2002) proposed along these lines that the evaluation results in the observation of the efficiency of teaching. ESP assessment is an apprenticeship aid. This gives students a sense of achievement and a sense that the assessment process is covered by the teacher's expertise and skills. It also added that the evaluation combines advantages such as strengthening, building trust, dedication and developing strength. ESP assessment mainly allows students to perform such communicative activities, provides input on learning, identifies the skills they master and underlines the skills that require extra effort, facilitates learning and tracks progress. Douglas (2000, p.10) cites tests that reflect the use of the vocabulary that has been designed, where students' capacities and skills are best assessed.

As language skills apply to what the learner can do in and with the target language, what really counts in the evaluation of the ESP is whether the student can use the target language to communicate and use the field know-how to achieve his/her objectives to understand and understand the English massage? Therefore, the ESP area of evaluation is concerned with content, themes and topics for a particular discipline and includes a higher technical language level and a communication role that enables learners to communicate their importance more specifically in a particular academic, professional and vocational field. In this sense, the performance evaluation of each ESP evaluation can be defined as an assessment of competences needed to succeed in the language target in the context in which it is used, and the connections between language knowledge and content knowledge for specific purposes.

Another significant aspect of the ESP evaluation is its commitment to teaching students to learn, hear, speak or write the target language, as well as how well they are able to do with students. The secret to this evaluation is to offer students tasks that are close to real language in some way. In this respect, a case study of the use of the target language of learners and the particular awareness of the use of english for real communication must be based on the ESP method for review. Accordingly, the whole range of a typical event for real-life communication will, firstly, be chosen and established according testing criteria and, secondly, promote a more integrated and themed evaluation, where the tasks authentically characterize the realities of the learners. and finally, a test of this type will not become more true (Douglas, 2000, p.10).

\section{E. Subcategory of ESP}

In general, ESP can be divided into two categories - EOP, and EAP. ESP can be divided into two types (English for Academic Purposes). EOP is primarily taught in situations where students need to use English in their jobs, whereas EAP is for those who are prepared to join certain occupations. The ESP has also been 
divided into multiple goals, namely EPE and EEP (English for Employment Purposes). EPE is described as English with the goal of full-time permanent work combined with preparation for work and training for entrickment into a training curriculum. There are subdivisions in the EPE which include EVP (English for vocation purposes) and EAP (English for academic purposes. The EVP is intended for those preparing for work while the EAP covers a variety of academic disciplines in specific areas. Essentially EAP learning covers professional content. In context-specific fields for the preparation of the work, EOP and EPP participants learn English.

\section{F. Type of ESP}

David Carter (1983) identifies three types of ESP:

1. English as a restricted language,

2. English for Academic and Occupational Purposes, and

3. English with specific topics.

The language used by aviation controllers or waiters is a small example of English. In the sense that the repertoire required by an air controller is strictly restricted and can be calculated precisely situationally, as the spoken-language necessities of a dining-room waiter or an air-hostess might be. But these small repertoires are not languages, just as the book is not a tourist term. A limited 'language,' would not allow the speaker in new situations or in contexts outside the professional environment to communicate effectively (Mackay and Mountford: 1978, 4-5).

Carter's second form of ESP (1983) is academic and occupational English. Unlike Carter, which classifies English as academic and English as occupational, Dudley and Evans classify them into two main categories. Under the same ESP classification, they are divided by two main ESP categories. In the "Tree of ELT," the State EAP Courses often have a vocational competence aspect, although it is more associated with vocations often referred to as English for vocational purposes or Vocational English for second-language purposes (EVP). This was similar to Hutchinson and Waters in 1987: 19 (VESL). Carter's (1983) third form of ESP is English with particular subjects. This kind of ESP addresses the expected English needs of scientists needing, for example, English for post-graduate studies, for conferences or for work in foreign institutions.

Different from Carter, Hutchinson and Waters (1987: 19) in the "Tree of ELT" brake down ESP into:

1) English for Science and Technology (EST),

2) English for Business and Economics (EBE), and

3) English for Social Studies (ESS).

Each of these subject areas is further divided into two branches: English for Academic Purposes (EAP) and English for Occupational Purposes (EOP). It has been explained above that EAP courses often have a study skills component, whereas EOP is more related with vocational purposes, often called English for Vocational Purposes (EVP) or Vocational English as a Second Language (VESL).

\section{G. Instructional materials for ESP teaching}

Materials, particularly ESP courses, are a key part of any educational program. Learning material means any material designed to help learners and teachers gain knowledge, skills or opinions, or improve cognitive processes as a learning resource. The materials used in instruction may be printed or unprinted, and may include textbooks, technical materials, other training materials and testing. This includes both electronic and Web-based textbooks. Learning materials play important roles in language teaching as described in Cunnings worthy of being: a source for presentation, whether spoken or write, a source of learner practice and communication; a source of grammar, vocabulary, pronunciation and so on for student students; a source of stimulation and ideas for classroom work; a syllabus where the

The task of educational material is more than just what the learners should be taught, in particular in ESP teaching. Since it is structured to meet the needs of the students and is also a source of language and reference, it also acts as support for learning, encouragement and relaxation. ESP materials should aim at providing exposure to specialized genres and registers in ESP to encourage learning through cognitive processes, and provide the students with a framework and progress to follow, to inspire students to build attainable challenges and content and to provide tools for self-study outside school (Dudley-Evans, 1998).

Two concerns may need to be raised in selecting and production of instructional materials for ESP teaching. 
The language systems contribute to the structure of grammar, core vocabulary and structure of text. For the purposes of discipline-specific signification, language uses include speech acts, genres, social experiences and phrases. Both components of language are considered fundamental in science and technological writing to be grammatical structure and vocabular. This is focused on the assumption that while science and technology have the same grammar as general English, certain grammar structures and vocabulary articles are also used. Study of scientific and technical Barber texts revealed that passive tense was used in such a text as general English frequently and established a series of more probable subtechnical vocabulary articles (Barber, 1985).

Ideas on interpretation of texts may be associated with top-down approaches to reading and listening understanding in a second language. Top-down approaches allow students to use their experiences to assist in reading a text. Richards contrasts top-down approaches with bottom-up strategies that interpret interpretation as a mechanism to decipher successive levels of language to achieve meaning, from sound to word and expression. Context information can take many forms from a topical perspective including knowledge of the subject of speech, the situation and the script (Richards, 2001). Awareness of text organizational patterns can also be included. Martinez argues for a teaching lecture approach in ESP which builds students' knowledge of macro text patterns.

A genre is a language class and communication that takes place in unique cultures. A label is granted to the culture in which a genre emerges. In his research Tarone et al. investigating the application of active and passive type in journal papers in the astrophysics industry, Dudley-Evans traces the roots of the word genre in ESP. Genres are regarded in the groups and cultures to which the students of ESP aspire as clear modes of communication and existing practices. Instruction in the genres used in target groups is seen as a way to make students embrace them. In order to achieve the student's needs, the elements of the language system and language usage shall become extremely important. The material of the curricula must be carefully selected, organized and sequenced.

\section{CONCLUSION}

Three key points can be taken from the definition above: first absolute and fundamental characteristics. The attributes to be used to build end-to-end and permanent ESP learning are absolute and fundamental. Secondly, features that are optional or more reliable can be classified with a term or expression that is better or more suitable. Therefore, these features can still be partially or fully modified in the ESP learning process, or can be improved, created and adapted. These modifications and changes depend on the ESP context. The definition of the ESP subdivision in which the EOP and the EPP can be combined in EOP (EEP), as both apply in the sense of the scope of work of the people who have been involved, whereas in Preparing for Jobs (EPE) EVP and EAP can be combined in English because the context of both universities and training of students is applied.

In various types of language surveys in ESP, definitions of speech acts, genres and social interaction formulas used in the professional, workplace, and academic environments can be seen a practical view of the language (language use). Therefore, it is clear that attempts are often made to identify how terms are used to convey basic principles of discipline in some fields (such as economy or law). Statements of behavior relevant to each speaker's or author's communicative intentions and described, for example, by the reason of the speaker using language to make an application, excuse and study. Speech activities are a central concept in pragmatics, in the study of the intention of the speaker and in the meaning of speakers when using a specific language. Ideas on speech acts complement the practical program.

\section{REFERENCES}

Basturkmen, H. (2006). Ideas and options in English for specific purposes. New Jersey: Lawrence Erlbaum Associates, Inc., Publishers.

Douglas, D. (2000). Assessing Language for Specific Purposes. Cambridge: Cambridge University Press.

Dudley-Evans, T \& St John, M J. (1998). Development in English for Specific Purposes.Cambridge: Cambridge University Press, page 1 .

Findley, C. A. \& L. A. Nathan. (1980). Functional Language Objectives in a Competency-based ESL Curriculum. Tesol Quarterly, 14(2).

Hutchinson, T \& Waters, A. (1987). English for Specific Purposes, A Learningcentered Approach. Cambridge: Cambridge University Press. 
https://www.quora.com/What-is-ESP-“English-for-Specific-Purposes online 12/01/2021

M. Aminah. https://inhaerin.wordpress.com/2018/02/08/pengantar-esp-english-for-specific-purposes online 12/01/2021

Maxwell Sim Yik Seng, M.A. (2013). Applied Linguistics \& English for Specific Purposes, Universiti Putra Malaysia.

Richards, J. C. (2001). Curriculum Development in Language Teaching. Cambridge: Cambridge University Press.

Richards. J. C. \& Renandya, W. A. (2002). Methodology in Language Teaching: an Anthology of current practice. Cambridge: Cambridge University

Richards, Jack C and Rodgers, Theodore S., ( 2001). Approaches and Methods in Language Teaching, Cambridge University Press., Cambridge

Robinson, P. C. (1991). ESP Today: Practitioner's Guide. New York: Prentice Hall

Vits, Alice. (2017). BA in English language and Literature, Ma in Translation

Strevens, Peter, 1988, ESP after twenty years, a re-appraisal in ESP State of the Art, SEAMEO Regional Language Centre

Stern in Basturkmen, H. (2006). Ideas and options in English for specific purposes. New Jersey: Lawrence Erlbaum Associates, Inc., Publishers.

Asrifan, A. (2009). Using songs in teaching English language for the young learners. ParePare: unpublished.

Puasa, K., Asrifan, A., \& Chen, Y. (2017). Classroom Talk in Bilingual Class Interaction. Research in Pedagogy, 7(1), 106-121.

Nadirah, N., Tahir, M. H., \& Asrifan, A. (2019). THE ABILITY TO TRANSLATE ENGLISH PHRASES INTO INDONESIAN AND THE DIFFICULTIES FACED BY THE ELEVENTH GRADE STUDENTS OF SMAN 1 PANCARIJANG. JOURNAL OF ADVANCED ENGLISH STUDIES, 2(1), 41-46.

Apdy, A. P. R., \& Asrifan, A. (2019, April). The Chinese mime game in teaching vocabulary on EFL classroom. In PROCEEDINGS OF THE 65th TEFLIN INTERNATIONAL CONFERENCE (Vol. 65, No. 01).

Taslim, T., Asrifan, A., Chen, Y., \& Nurdania, N. R. (2019). CORRELATION BETWEEN STUDENT'S VOCABULARY MASTERY AND SPEAKING SKILL. JOURNAL OF ADVANCED ENGLISH STUDIES, 2(2), 65-76.

Muthmainnah, M., Asrifan, A., Al Yakin, A., \& Sahabuddin, C. (2019, April). The use of dictogloss technique on ELT classroom: An experiment study of students listening comprehension. In PROCEEDINGS OF THE 65th TEFLIN INTERNATIONAL CONFERENCE (Vol. 65, No. 01).

Mutmainnah, M., Azis, S., Maulidya, U., \& Asrifan, A. (2017). Glory Style in Mandar Song Lyrics: A study of Mandar Tribe in South Sulawesi, Indonesia. JOURNAL OF ADVANCES IN LINGUISTICS, 8(1), 12861291.

Asrifan, A., Rinantanti, Y., Tang, S., \& Nadirah, N. (2019). THE 3-DIMENSION PICTURES IN INCREASING THE STUDENTS ABILITY AND INTEREST TO WRITE DESCRIPTIVE COMPOSITION. JOURNAL OF ADVANCED ENGLISH STUDIES, 2(1), 19-30.

Asrifan, A., Nadira, N., \& Haedar, H. (2018). IMPROVING STUDENTS'READING COMPREHENSION OF DESCRIPTIVE TEXT THROUGH COLLABORATIVE MURDER. JOURNAL OF ADVANCED ENGLISH STUDIES, 1(2), 21-31.

Asrifan, A. (2015). Analysis of English Students' Learning Style in Bilingual Class. International Journal of Literature and Arts, 3(4), 34.

Farahdiba, S., \& Asrifan, A. (2016). Speaking Ability and Psychological Barriers of the Second Year Students of Hotel Department of SMKN 1 Sidenreng Kabupaten Sidrap in Speaking English. Asian EFL Journal, (89), 41.

Asrifan, A. (2012). Increasing the Students Ability to Write Descriptive Composition at SMP Negeri 13 Parepare by using the 3-Dimension Pictures.

Tang, S., Asrifan, A., Chen, Y., Haedar, H., \& Agussalim, M. (2019). THE HUMOR STORY IN TEACHING READING COMPREHENSION. JOURNAL OF ADVANCED ENGLISH STUDIES, 2(2), 77-87.

Nurwanti, N., Asrifan, A., \& Haedar, H. (2019). THE APPLICATION OF COOPERATIVE LEARNING: JIGSAW II TECHNIQUE IN IMPROVING STUDENTS'READING COMPREHENSION OF EXPOSITORY TEXT. JOURNAL OF ADVANCED ENGLISH STUDIES, 2(1), 31-40.

Asrifan, A. (2016). The Effectiveness of Think-Pair-Share Technique in Improving Studentsâ€ ${ }^{\mathrm{TM}}$ Speaking Ability and Interest. English Literature and Language Review, 2(3), 24-35.

Asrifan, A., Muthmainnah, M., Al-Yakin, A., Sahabuddin, C., \& Haedar, H. (2018). THE CAUSE-EFFECT TECHNIQUE IN TEACHING RECOUNT WRITING. JOURNAL OF ADVANCED ENGLISH STUDIES, 1(2), 63-72.

Asrifan, A., Vargheese, K. J., Syamsu, T., \& Amir, M. (2020). ESP COURSE DESIGN: THE NEED ANALYSIS ON TOURISM DEPARTMENT IN INDONESIA VOCATIONAL HIGH SCHOOLS. JOURNAL OF ADVANCED ENGLISH STUDIES, 3(2), 69-77. 
Asrifan, A., Ghofur, A., \& Azizah, N. (2020). Cheating Behavior in EFL Classroom (A Case Study at Elementary School in Sidenreng Rappang Regency). OKARA: Jurnal Bahasa dan Sastra, 14(2), 279-297.

Nadirah, N., Asrifan, A., Vargheese, K. J., \& Haedar, H. (2020). INTERACTIVE MULTIMEDIA IN EFL CLASSROOM: A STUDY OF TEACHING READING COMPREHENSION AT JUNIOR HIGH SCHOOL IN INDONESIA. JOURNAL OF ADVANCED ENGLISH STUDIES, 3(2), 131-145.

Muthmainnah, A. R., Atmowardoyo, H., Salija, K., \& Asrifan, A. (2020). Literary Work as Teaching Materials: A Study of Students and Lecturers Needs Analysis. Solid State Technology, 63(5), 394-407.

Tilome, A. A., Agustang, A., Jasruddin, M. S., \& Asrifan, A. (2020). Social Exchange of Political Elites in the Regional Leader Election of Gorontalo Province, Indonesia. Solid State Technology, 63(5), 521-531.

Pacinongi, A., \& Asrifan, A. (2020). Bimbingan Pengawas Berkelanjutan dalam Mewujudkan Pendidikan Karakter Bangsa dalam Kegiatan Belajar Mengajar Penjaskes. Celebes Education Review, 2(1), 1-7.

Gunawan, G., \& Asrifan, A. (2020). Penerapan Kerja Kelompok Kegiatan MGMP Guru Ekonomi dalam Menyusun RPP untuk Meningkatkan Kompetensi Pedagogik. Celebes Education Review, 2(1), 31-36.

Yusuf, I., \& Asrifan, A. PENINGKATAN AKTIVITAS KOLABORASI PEMBELAJARAN FISIKA MELALUI PENDEKATAN STEM DENGAN PURWARUPA PADA SISWA KELAS XI IPA SMAN 5 YOGYAKARTA. Editorial Team, 32.

Al Yakin, A., Sahabuddin, C., Rahayu, A., Fitrah, N., \& Arifin, M. (2020). Political Celebrification and Electability: A Study of Political Phenomena Imaging in Election Polewali Mandar District, West Sulawesi, Indonesia. Solid State Technology, 63(5), 632-646.

Junaedah, S. B. T., \& Ahmad, M. A. (2020). The Outdoor Learning Modules Based on Traditional Games in Improving Prosocial Behaviour of Early Childhood. International Education Studies, 13(10).

Octaberlina, L. R., \& Muslimin, A. I. (2020). Efl students perspective towards online learning barriers and alternatives using moodle/google classroom during covid-19 pandemic. International Journal of Higher Education, 9(6), 1-9.

Octaberlina, L. R., \& Anggarini, I. F. (2020). Teaching vocabulary through picture cards in Islamic Elementary School: a case study in Nida Suksa School, Thailand. Jurnal Madrasah, 13(1), 26-38.

Octaberlina, L. R. (2016). Plagiarism in English language theses in Indonesia. Jurnal Ilmu Pendidikan, 14(3).

Octaberlina, L. R., \& Anggarini, I. F. (2020). Teaching vocabulary through picture cards in Islamic Elementary School: a case study in Nida Suksa School, Thailand. Jurnal Madrasah, 13(1), 26-38.

Asrifan, A., Zita, C. T., Vargheese, K. J., Syamsu, T., \& Amir, M. (2020). THE EFFECTS OF CALL (COMPUTER ASSISTED LANGUAGE LEARNING) TOWARD THE STUDENTS'ENGLISH ACHIEVEMENT AND ATTITUDE. JOURNAL OF ADVANCED ENGLISH STUDIES, 3(2), 94-106.

Asrifan, A. (2021). ACADEMIC WRITING. LawArXiv. January, 2. https://doi.org/10.31228/osf.io/x2s7e

Asrifan, A. (2020). TUTORIAL PENGGUNAAN QUIZIZZ (www. quizizz. com) PADA PEMBELAJARAN. https://doi.org/10.31219/osf.io/kqnza

Asrifan, A. (2021). Abd Ghofur.“. THE USE OF READING CIRCLES IN INCREASING STUDENTS SPEAKING ABILITY AT THE ELEVENTH GRADE SMK NEGERI, 1. https://doi.org/10.31219/osf.io/8vjxy

Asrifan, A. (2020). Pandemic, Humanity and Education. https://doi.org/10.31219/osf.io/q2gpk

Asrifan, A. (2021). USING CAT AND MOUSE GAME TO IMPROVE STUDENT'S SPEAKING ABILITY AT THE ELEVENTH GRADE OF MA YMPI RAPPANG. https://doi.org/10.31219/osf.io/phtvn

Asrifan, A., \& Ghofur, A. (2021). THE USE OF READING CIRCLES IN INCREASING STUDENTS SPEAKING ABILITY AT THE ELEVENTH GRADE SMK NEGERI 1 PANCARIJANG. https://doi.org/10.31219/osf.io/8vjxy

Asrifan, A. (2021). Book Review: Halliday. 1989. Spoken and Written Language. Oxford University Press. https://doi.org/10.31219/osf.io/ej8tb

Asrifan, A., \& Ghofur, A. (2021). TALK, ACTION, SILENCE, INTERRUPTION AND THEIR IMPLICATIONS IN BUGINESE SOCIETY (SOPPENG REGENCY). https://doi.org/10.31219/osf.io/pv3ku

Asrifan, A. (2020). PENILAIAN BERBASIS ANDROID MENGGUNAKAN APLIKASI PLICKERS. https://doi.org/10.31219/osf.io/htreq

Haulussy, R. H., Najamuddin, I. R., \& Agustang, A. D. M. P. (2020). The sustainability of the Sasi Lola tradition and customary law (Case study in Masawoy Maluku, Indonesia). Intl J Sci Technol Res, 9(2), 5193-5195.

Arwan, A., Agustang, A., Arlin, A., Yani, A., \& PUTRA, D. M. (2019). Contestation of Elite Discourse in Treatment of HIV and AIDS. Iranian Journal of Public Health, 48(12), 2205.

Mutiara, I. A., Agustang, A., Adam, A., Upe, A., \& Equatora, M. A. (2020). The dynamics of prostitutes lives in metropolitan cities. Journal of Critical Reviews. https://doi. org/10.31838/jcr, 7, 165.

Usman, A., Agustang, A., Djalal, D., \& Annas, S. (2018, October). The Contribution Of Supporter Community In Maximizing Their Role For The Advancement Of Makassar Football Club (PSM). In 1st International 
Conference on Social Sciences (ICSS 2018). Atlantis Press.

Ma'na, P., Agustang, A., Salusu, J., Ikhsan, A., \& Dirawan, G. D. (2015). Decision making strategic value based local wisdom Tongkonan North Toraja. Man India, 95(3), 633-639.

Dirawan, G. D. FOSTERING COLLABORATION STREET CHILDREN IN MAKASSAR. Man In India, 95(3), 569-576.

Abdurachman, A. D. M. P. A., \& Agustang, A. Culture Of Shame-Heart And Social Solidarity Of Kaitetu People Central Maluku District, Indonesia.

Aida, K. N., Agustang, A., Arlin, A., \& Agustang, A. D. M. The Patron-Client Relationship Patterns In Siwa Lima Fishermen Community, Aru Islands District Maluku, Indonesia.

Pannyiwi, R., Agustang, A., Kasnawi, T., Pada, A. T., Yani, A., \& Syam, S. (2020). Social Network for Drug Circulation in Sidenreng Rappang Regency, Indonesia. Systematic Reviews in Pharmacy, 11(9), 575-577.

Upe, A., Salman, D., \& Agustang, A. (2019). The effects of the exploitation of natural resources towards risk society construction in Southeast Sulawesi Province, Indonesia. Journal of Degraded and Mining Lands Management, 6(2), 1587.

Matakena, F., Watloly, A., Agustang, A., Adam, A., \& Alim, A. (2020). The Self-Concept of Ale Rasa Beta Rasa in the Orang Basudara Community in Ambon (Studies on the Community of Passo and Batumerah Country). International Journal, 9, 1307.

Asmi, A. S., Kasnawi, M. T., Agustang, A., \& Yani, A. (2020). Sociocultural Transformation in Efforts to Reduce Mortality of Infants in Bone Regency, Indonesia. Systematic Reviews in Pharmacy, 11(10), 762765.

Usmana, A., \& Agustangb, A. The Implementation of "Arif” Social Behaviour within Perssin Supporters in Sinjai District.

Hasan, I. R., Agustang, A., Kahar, F., \& Tahir, H. (2019). Super Service Delivery": an advanced conceptual model of one-stop service for wide administrative region. Problems and perspectives in management, (17, Iss. 1), 189-201. 